\title{
Business Ethics in Contemporary China: Key Issues and Solutions
}

\author{
Hong-Ye Liu, ${ }^{1, a}$, Xiao-Wen Jie ${ }^{2, b,{ }^{*}}$ \\ ${ }^{1,2}$ Business School, Sichuan University, Chengdu, 610064, P. R. China \\ aliuhy@xbmu.edu.cn, bjiexw@vip.163.com \\ ${ }^{*}$ Corresponding author
}

Keywords: Business ethics, Consumer's rights, Corporate social responsibility, Regulation.

\begin{abstract}
Ethical behavior is essential for long- term business success. This article examines some ethical issues that emerged from business in the context of China's transition economy. Four key issues - consumer's rights, safety in workplace, environmental pollution, and corporate social responsibility - are discussed. The article concludes by offering some solutions which would be effective to solve those ethical issues.
\end{abstract}

\section{Introduction}

The economic success of China has had a significant impact on standard of living for the majority. However, business ethics lags behind the economic growth in China. Some ethical issues in business are controversial both in practice and in theory. This article begins by examining the relationship between business ethics and the law. Next, key ethical issues in business, including consumer's rights, safety in workplace, environmental pollution, and corporate social responsibility are discussed. Finally, this article explores the solutions of the ethical issues in three ways: implementation of law and regulation, development of code of ethics, and the role of government.

\section{Business ethics and the law}

Business ethics is the study of business activity from a moral point of view. It is about rights and wrongs in the world of business. One might question whether this is in any way distinct from the law. Surely the law is also about issues of right and wrong? There is indeed considerable overlap between ethics and law. Nonetheless, the two are not equivalent. Perhaps the best the way of thinking about ethics and the law is in terms of two intersecting domains (see Figure 1). The law might be said to be a definition of the minimum acceptable standards of behavior. However, many morally issues, whether in business or elsewhere, are not explicitly covered by the law.

Business ethics is primarily concerned with those issues not covered by the law, or where is no definite consensus on whether something is right or wrong, for example, advertising directly to children and it is not illegal. Crane and Matten (2004) argued that, discussion about the ethics of particular business practices may eventually lead to legislation once some kind of consensus is reached, but for most of the issues of interest to business ethics, the law typically does not provide us with guidance. For this reason, it is often said that business ethics is about the 'grey area' of business.

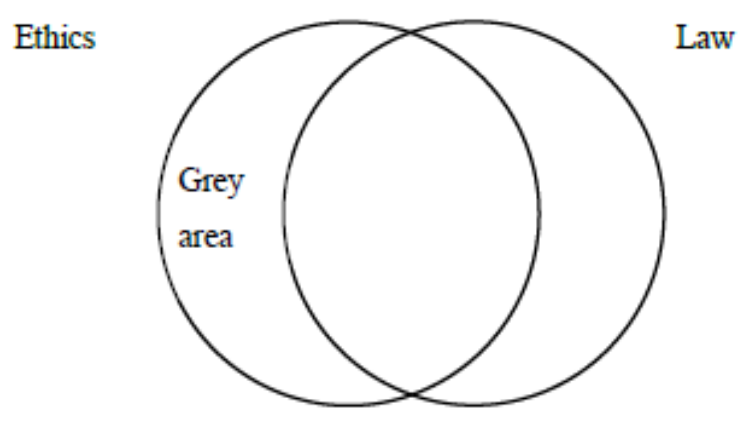

Fig.1 The relationship between ethics and the law 


\section{Key issues and debates}

With the rapid development of China's economy, ethical issues in business is increasingly recognized by businessmen and academics. Some ethical issues, such as consumer's rights, safety in workplace, environmental pollution, corporate social responsibility, and so on, are becoming controversial topics in china in recent years.

\section{Consumers' rights}

There have been many, increasingly significant business scandals over the past two decades in China, some of them are related to the consumer's rights, for example, the 2008 milk scandal, a food safety incident involving milk and infant formula adulterated with melamine. The issue raised concerns about food safety and consumer's right, and damaged the reputation of China's food exports with at least 11 countries stopping all imports of Chinese dairy products.

\section{Safety in workplace}

The problems of unsafe workplaces such as mining accident, was in large part created by the drive for efficiency in the marketplace. Workers' safety is often ignored in China's collieries in the quest for quick profits and the drive to meet surging demand for coal.

\section{Environmental pollution}

In China, environmental pollution mainly comes from industrial process. By economizing in the use of resources and disposing of its waste material as cheaply as possible by dumping it into the air, business was causing some pollution problems regarding air quality and poisoning of drinking water.

The demand for a clean and healthy environment has grown and is higher today than it has been in China. For example, Lanzhou, the capital city of Gansu province in northwest China, is one of China's chemical industrial centers. On the one hand, there are chemical factories, steel factories, textile factories, and power plants, it is unavoidable for these factories to dump waste pollutes into the air and the River Yellow with less environmental regulation. On the other hand, local residents really have done something, such as planting trees, greening the bare mountains to improve environmental quality.

From the view of economist, the question is, does the firm has the right to pollute the air or the residents have the right to enjoy the fresh air. (Ronald Coase 1960) The coase theorem states that if property rights exist and transactions cost are low, the individual choices of people in markets lead to the efficient quantity even when external costs exist (Parkin et al. 2003).

\section{Corporate social responsibility}

The issue of corporate social responsibility (CSR) was introduced to China in 1990s, and was due to China is the supplier of many global corporations. CSR is an idea that business has social obligations above and beyond making a profit (Kreitner 2004).

There are two opposing views of CSR (Robinson and Coulter 1996). On one side, there is the classical view that the only social responsibility of business is to making maximize profits for stockholders (Friedman 1962, 1970). On the other side, the socioeconomic view which holds that management's responsibility goes well beyond making profits to include protecting and improving society's welfare. Porter (2006) argued that CSR can be much more than a cost, a constraint, or charitable deed - it can be a source of opportunity, innovation, and competitive advantage.

\section{Solutions}

Put the key issues into the background of China's transitional economy, it is not difficult to find the tension between profit and morality which Chinese business firms have been confronted. China is in the process from the planned economy system into the market economy system. Institutional change is the central and most consequential contextual aspects of China's transition. (Child and Tse 2001, Peng 2003). Considering the impact of institutional change to business, the key issues are 
likely associated with institutional change. I think the ethical issues emerging in business can be resolved in three ways: implementation of law and regulation, development of code of ethics, and the role of government.

\section{Implement law and regulation}

The ethical issues in business are mostly caused by lack of law and regulation in contemporary China. Laws and regulations are urgently needed, to control the sale of many products, to protect trading standards, to provide customer protection and to regulate forms of advertising.

Regulation was relied on to change corporate behavior and makes the corporation moral by forcing it, for example, to clean up its pollution and in this way make another kind of contribution to social welfare. Regulation forces business to internalize the social costs of production and take social impacts that it might otherwise ignore into account in the production and pricing of products (Buchholz 1989).

\section{Develop code of ethics}

Code of ethics is a form of self-regulation, and it embodies the commitment of a company to its stakeholders, particularly its customers (Becker 2008). Some leading international corporations such as Johnson \& Johnson, IBM, and Starbucks, they all established and implemented their codes of ethics. McHugh (1991) recommended that, relying on internal mechanism of self-control or self-regulation involves institutionalizing ethics and moral concerns into the corporation itself. Moral concerns must be integrated into daily business operations, making ethics a normal and regular part of doing business. This involves integrating ethics into policy making at all levels of the organization and into decision-making and work practices of all employees.

\section{The role of government}

Governments are essential in improving corporate behavior in China, because governments usually play a prominent role in economic and social affairs in the country's long administrative tradition. China's transition continues to be planned by the state and preserves an active involvement of governmental institutions in business affairs (Child and Tse 2001). From some ethical issues, for instance, Sanlu baby milk case, we can find independent regulation was lacking or ineffective as local industries' were so intertwined with local officialdom. The effectiveness of law and regulation depends on a strong and well-functioning government.

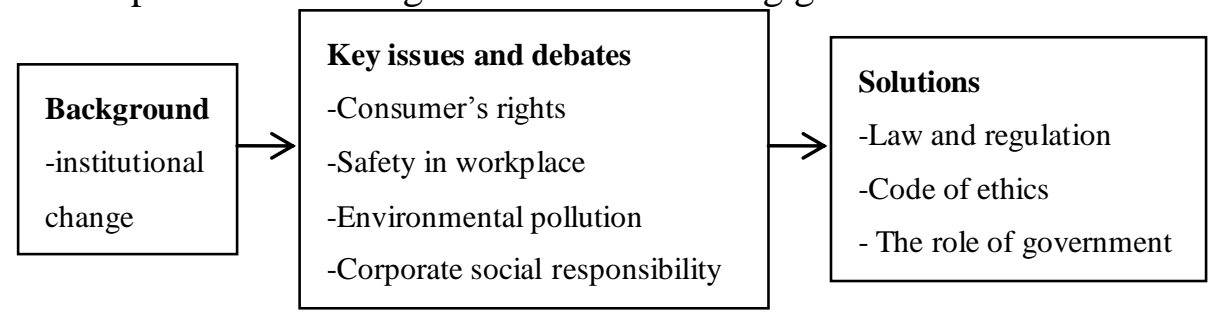

Fig.2 The relationship between background, ethical issues and solutions

\section{Conclusion}

This article has examined key ethical issues in business in contemporary China, and offers some solutions which would be effective to solve those ethical issues. The relationship between Background, ethical issues and solutions is summarized in Figure 2. Although ethical issues have damaged the reputation of Chinese firm heavily, it does not mean there are not good firms in China. Some leading corporations have paid great attention to the business ethics, for example, codes of ethics have been established and implemented as strategy in many corporations, and it is a good thing for Chinese business firms from the long-term point of view.

The ethical challenges experienced by China present the opportunity for Chinese-based enterprises to return to traditional Chinese ethical culture, Confucian history, and honor-based transactions (Becker 2008). Sima Qian, historian of Han dynasty, wrote in his book Records of the 
Historian: 'The best kind of wealth comes from farming, the next best from trade and handicrafts, and the worst from evil practices.' 'Just as fish multiply in deep lakes and wild beasts flock to deep mountains, humanity and justice follow riches.' Ethical behavior is essential for long- term business success. From the historical point of view, it takes time and efforts to improving business ethics in China.

\section{References}

[1] A. C. Nicholas, Purpose and policy, Journal of Business Ethics. 1 (1982) 1-2.

[2] A. Crane and D. Matten, Business Ethics: A European Perspective, Oxford university press, New York, 2004.

[3] M. Parkin, M. Powell, K. Matthews, Economics, fifth ed., Pearson Education Limited, London, 2003.

[4] R. Kreitner, Management, ninth ed., Houghton Mifflin Company, Boston, 2004.

[5] D. S. Sherwin, The ethical roots of the business system, Harvard Business Review. November-December (1983) 183-192.

[6] M. Friedman, Capitalism and Freedom, The University of Chicago Press, Chicago, 1962.

[7] S. P. Robinson, M. Coulter, Management, Prentice Hall, New Jersey, 1996.

[8] G. G. Brenkert, The limits and prospects of business ethics, Business Ethics Quarterly. 20:4 (2010) 703-709.

[9] M. E. Porter, M. R. Kramer, Strategy \&society: the link between competitive advantage and corporate social responsibility, Harvard Business Review. December (2006) 78-92.

[10] J. Child and D. K. Tse, China's transition and its implications for international business, Journal of International Business Studies. 32, 1 ( 2001) 5-21.

[11] M. W. Peng, Institutional transitions and strategic choice, Academy of Management Review. 2 (2003) 275-296.

[12] F. P. McHugh, Ethics, Macmillan Education Ltd, London, 1991.

[13] R. A. Buchholz, Fundamental Concepts and Problems in Business Ethics, Prentice-Hall, Inc., New Jersey, 1989.

[14]P. A. Becker, The ethical challenges for enterprise and risk to consumers of large market share through low-cost supplier strategy, Journal of International Business Ethics. 1(2008) 107-113. 